\title{
THE CHANGE OF FORESTS AND THEIR AREA IN LITHUANIA
}

\author{
Giedrè Ivavičiūtė \\ Aleksandras Stulginskis University, Lithuania \\ Kaunas Forestry and Environmental Engineering University of Applied Sciences, Lithuania \\ Klaipèda State University of Applied Sciences, Lithuania \\ ivavice@gmail.com
}

\begin{abstract}
The article presents an analysis of the existing situation of forests of the Republic of Lithuania. The situation is analysed in ten counties of the country. In the Republic of Lithuania, forests occupied 2,178,958.04 ha, country's forest coverage - 33.38\% in 2017. The highest forest coverage was established in Alytus (48.80\%) and Vilnius (43.47\%) counties. Only in three counties of Lithuania (Panevėžys, Telšiai and Utena) the prevailing type of ownership is private forests. In all counties of Lithuania mostly there are Group IV commercial forests, which make up 71.4\% of the total forest area. The least are Group I reserved forests. Coniferous species (56.2\%) prevail in the country's forests, of which pine forests are dominant. It is crucial today to analyse the current state of forests and anticipate changes in trends, preventing potential threats. Following the analysis of Lithuanian forest change, it was determined that during the period between the years 2006 and 2017, the forest area increased by 78,616.40 ha or 3.74\%. The largest forest development took place in Utena $(17,324.13$ ha or $7.32 \%)$ and Šiauliai $(14,798.15$ ha or $6.87 \%)$ counties. In order to implement the forestry development prospects, from 2018 to 2030, 106,068.87 ha of forests should be planted. In 2030, 2,285,026.91 hectares of forest would occupy Lithuania and would make up to 35\% of the country's area.
\end{abstract}

Key words: landscape, forest, forest land.

\section{Introduction}

Article relevance. Landscape is a natural and pulsating natural and anthropogenic system, undergoing complex changes, which can be divided into two groups corresponding to two directions of change - naturalization and anthropogenization. These two groups of forces change the landscape in the eyes of modern mankind (Pranckietis et al., 2010). Forests, as the most important biological recovering resource, play an important role in people's lives. At present, increasing attention is devoted to the ecological and protective functions of forest landscape.

Forests are important both in terms of environmental and socio-economic aspects. From an environmental point of view, forests carry out ecosystem storage functions: contributing to soil conservation, climate regulation, and biodiversity conservation.

Forests are important sources of livelihoods to millions of people and contribute to national economic development of many countries (Kohl et al., 2015).

Problem. In Lithuania, an intensive, marketoriented agricultural and forestry practice is being developed that promotes soil degradation, landslide loss and threats to biodiversity and sustainability of forest and aquatic ecosystems. The accelerated climate change affects all ecosystem components and their functions, forms new environmental conditions not analogous to the history of Lithuania. The emerging phenomena of ecosystem degradation are complicated, difficult to manage, and need to be explored in a complex manner.

The Republic of Lithuania Forestry Law (Lietuvos, 1994) states that "forest is defined as a tract of land not less than 0.1 ha, covered by trees or other forest vegetation of a gravity of at least 0.3 and the height of which at the natural plant site in the age of maturity is at least 5 meters, and another forest vegetation, as well as a land of at least 0.1 hectare, where the stand has become scattered and it does not temporarily contain trees (forest plantations, clearing sites, fallen forests) because of human activity or natural factors ".

It is estimated that 10.000 years ago the forests covered 65.8 million $\mathrm{km}^{2}$ or almost 50 percent of the total land area. During the industrial revolution that began in the middle of the XVIII century, about 16 million $\mathrm{km}^{2}$ of forests were cut down, mainly for agricultural purposes, for house and ship building (Christensen, 2012).

In Europe, forested areas have remained little changed over the last 20 years. They cover 45 percent of land area. In the continent, in the 20-year period, 1.6 percent of forest area increase has been determined (Food, 2015).

Forests are a very important part of the global carbon cycle because they remove carbon dioxide $\left(\mathrm{CO}_{2}\right)$ from the atmosphere and accumulate carbon in biomass and soil. Forests help to limit the concentration of greenhouse gases in the atmosphere. On the other hand, deforestation and / or land use change can lead to fires, biomass depletion and / or mineralization of soil organic matter, which can lead to a significant increase in greenhouse gas emissions and forests to become sources of $\mathrm{CO}_{2}$ (European, 2010).

The decline of forest ecosystem types and their occupied areas directly relates to World civilizations in the historical period. Historical degradation of forest ecosystems often correlates directly with demographic processes - population growth and their further development. The main causes of direct 
deforestation were and are: the use of cultivated land and timber (industry and fuel), the restoration of other forest resources, and intensive abandonment. Other disguised reasons include the poverty of local people, the rapid increase in their numbers, the presence of forest products, etc. demand in world markets and intensive trade, as well as macroeconomic policies. At the end of the 20th century, the rate of tropical deforestation reached 1\% of their total area per year (Balevičius et al., 2007).

Disturbances, both human-induced and natural, shape forest systems by influencing their composition, structure, and functional processes (Dale et al., 2001).

Many scientists are concerned about the negative effects of climate change on forests and their ecosystems.

Global warming is a well-known natural phenomenon that needs to be controlled for environmental conservation (Khaine \& Woo, 2014). Climate change presents significant potential risks to forests and challenges for forest managers. Adaptation to climate change involves monitoring and anticipating change and undertaking actions to avoid the negative consequences and to take advantage of potential benefits of those changes (Keenan, 2015). Climate change is likely to have a major impact on different tree species and will greatly affect biodiversity and the economy (Čapkauskas, 2016).

Many forests can be managed to both adapt to climate change and minimize the undesirable effects of expected increases in tree mortality. The uncertainties inherent to climate change effects can be diminished by conducting research, assessing risks, and linking results to forest policy, planning and decision making (Sturrock et al., 2011).

Landscape, including forests, is a very complex, territorially differentiated system; therefore, it is not easy to select objective criteria that can be used to uniquely assess the state of the landscapes of a particular country or region, to reveal the causality of change (Pileckas, 2004).

The object of this article is the forests of the Republic of Lithuania.

The aim of the work is to perform the analysis of forest area change in the Republic of Lithuania during 2006 - 2017.

Tasks to be solved:

1. To examine the current state of Lithuanian forests.

2. To analyse the changes in forest areas of the Republic of Lithuania in 2006 - 2017.

3. To anticipate trends in forest area changes.

\section{Materials and Methods}

Comparative, analytical as well as statistical and logical analysis methods were used for the research.
The land fund statistics of the Republic of Lithuania (Nacionaliné žemès, 2006-2017), graphically depicted in figures, were used for the fulfilment of the research of the forest area change in Lithuania for the years 2006 - 2017.

The article analyses works of foreign and Lithuanian scientists, published in scientific publications, conferences. The legal acts, regulations, conventions, strategies and programs of the European Union (EU) and the Republic of Lithuania are also examined.

In this work, the forest coverage analysis of the Lithuanian counties was carried out, the prevailing tree species and age were determined, the distribution of forests by groups and ownership type was investigated.

The article presents the analysis of forest area change in the counties and the Republic of Lithuania in 2006 - 2017. The following planning documents are used for the work: General Plan of the Republic of Lithuania, National Landscape Management Plan, etc.

\section{Results and Discussion}

Analysis of the current state offorests. According to the data of 2017, forests occupy 2,178,958.04 hectares in the Republic of Lithuania, and the country's forest coverage is 33.38 percent. Forests in the territory of the country are distributed unevenly (Fig. 1). The most forested is Dzūkija, but the least forested region is Suvalkija.

After analysing the current state of the forests in the Republic of Lithuania, it has been established that the most forested are Alytus (48.80\%), Vilnius (43.47\%), Telšiai (36.30\%), Utena (35.30\%), and Tauragè (33.45 percent) counties. In the mentioned counties, the forest coverage is higher than the average of the Republic of Lithuania (33.38 percent). In the remaining counties, forest coverage is below the national average. It was found that the least forested was Marijampole county (21.70\%) (Fig. 2).

Coniferous species (56.2\%) prevail in the country's forests, of which pine forests are dominant. Pine trees grow in the area of 727.1 thousand ha. Overgrown with softwood foliage are 816.1 thousand ha (39.7\%), with hardwoods - 83.8 thousand ha (4.1\%) (Fig. 3).

In the study of forests according to their age, it was found that in the five counties (Alytus, Tauragè, Telšiai, Utena, Vilnius), prevail forests of 50-59 years old. In the remaining counties, i.e. Kaunas, Klaipeda, Marijampolé, Panevėžys and Šiauliai, there are $60-$ 69 years old forests.

In all of Lithuania's counties, there are mostly Group IV commercial forests. These forests make up $71.4 \%$, where the main purpose of farming is to form productive stands to continuously supply wood. The least are Group I forest reserves (1.2\%) (Fig. 4). 
By analysing forests according to the type of ownership, it has been established that in the counties are predominantly forests of state importance managed by state enterprises, National Parks and state reserves. Only in three counties (Panevėžys, Telšiai and Utena) the predominant types of ownership are private and other forests.

It is crucial today to analyse the current state of forests and anticipate changes in trends, preventing potential threats.

Forest area change in counties and in the Republic of Lithuania. The tendencies of the change of landscape naturalness express the development of forest coverage. In the case of regional and general forest coverage tendencies, certain assumptions about the strengthening of natural weakly anthropogenic landscaping positions, and the increase of the compensatory potential of the natural framework are formed.

Lithuanian forest coverage in 1938 averaged 20.7 percent, in 1983 - 27.9\%, 1998 - 30.3\%, 2014 $32.6 \%$, in $2017-33.38 \%$.

There are ten counties and sixty municipalities in Lithuania. The article presents an analysis of the current state of forest and changes in counties and in the country.

In Alytus county, forests occupied 266,257.97 ha or $49.14 \%$ of the county's area in 2006. In 2017, the forest land occupied $264,363.18$ ha or $48.80 \%$. During the period of the years 2006 and 2017 the forest area decreased by $1,894.79$ ha or $0.71 \%$. Although during the years 2006-2017 the forest area was decreasing in the county, Alytus county remained the most wooded area of the country.

During the analysed period, the forest area in Kaunas county increased by $6,566.02$ ha or $2.79 \%$ and in 2017 occupied 242,029.42 ha.

In Klaipeda County, forests occupied 132,741.36 ha, i.e. 25.42 percent of the county's area in 2006. During the period of 2006-2017, the forest in the county area increased by $5,612.7$ ha or $4.23 \%$ and in 2017 it covered 138,354.06 ha and made up to 26.49 percent of the county's area.

The areas analysed in Marijampole county also grew. In the county, one of the lowest growths of forest areas has been determined over the analysed period compared to other counties. The forest area in 2006-2017 increased by 169.39 ha or $0.18 \%$ and in 2017 occupied $96,894.09$ ha, i.e. $21.70 \%$ of the county's area.

Panevežys county forests in 2006 accounted for $27.36 \%$, and in $2017-28.54 \%$ of the county's area. During the period under consideration, the area occupied by forests increased by 933879 ha or by $4.33 \%$.

Šiauliai county forests in 2006 occupied $220,114.76$ hectares and amounted to 25.78 percent of the county's area. Forests in 2006 - 2017 increased by $14,798.15$ ha (6.87\%) and amounted to 230,312.95 ha and made up $26.98 \%$ of the county's area.

In 2006, the Taurage county forests accounted for 32.19 percent and occupied 141,915.20 ha. During the period under consideration, the forest area increased by $5,543.66$ ha or $3.91 \%$. At present, the county's forest coverage is 33.45 percent $(147,458.86 \mathrm{ha})$.

Telšiai county has a higher forest coverage compared to the average in Lithuania. In 2017, the forest coverage in the county was $36.30 \%$, while in the Republic of Lithuania $-33.38 \%$. The area of forest land increased by 11,572.14 ha (7.93\%).

Utena county forests in 2017 amounted to $35.30 \%$ of the county area. During 2006-2017 the forest area increased by as much as $17,324.13$ ha or $7.32 \%$. The county has the largest forest area change in hectares in the Republic of Lithuania.

The forest coverage of Vilnius county is one of the largest in Lithuania - 43.47 percent. During the analysed period, the forest area increased by 13,886.17 ha or $3.39 \%$.

During the period between the years 2006 and 2017 the largest development of forest area took place in Utena (17,324.13 ha or $7.32 \%)$ and Šiauliai $(14,798.15$ ha or $6.87 \%)$ counties.

In the Republic of Lithuania forests occupied an area of 2,100,341.64 hectares in 2006. During 20062017 the area increased by $78,616.40$ ha or $3.74 \%$ (Fig. 5).

Thus, it was found that during the period of 2006-2017, the country's forest area increased from $32.17 \%$ in 2006 to $33.38 \%$ in 2017 (Fig. 6). The area has increased due to the implementation of the forest improvement program, the promotion of plantation forests, the promotion of self-help to forest regeneration, participation in the Rural Development Program, and EU payments for this.

As mentioned, the development of forests was driven by Rural Development Program (RDP). For example, $33 \%$ of the support for forest owners and managers for 2007 - 2013 was $10 \%$ from RDP funds. For the $2014-2020$ program period, also 10\% of all rural development support was paid.

During the period of 2014 - 2020 the following measures for the implementation of Rural Development are foreseen: investments into the development of forest areas and the improvement of forest vitality; afforestation and establishment of forest areas; establishment of agroforestry systems; forest fire, natural disasters and catastrophic damage prevention and remuneration; investments that increase the resilience and environmental value of forest ecosystems; investments in new forestry technologies and processing and marketing of forest products; payments related to Natura 2000; forest 


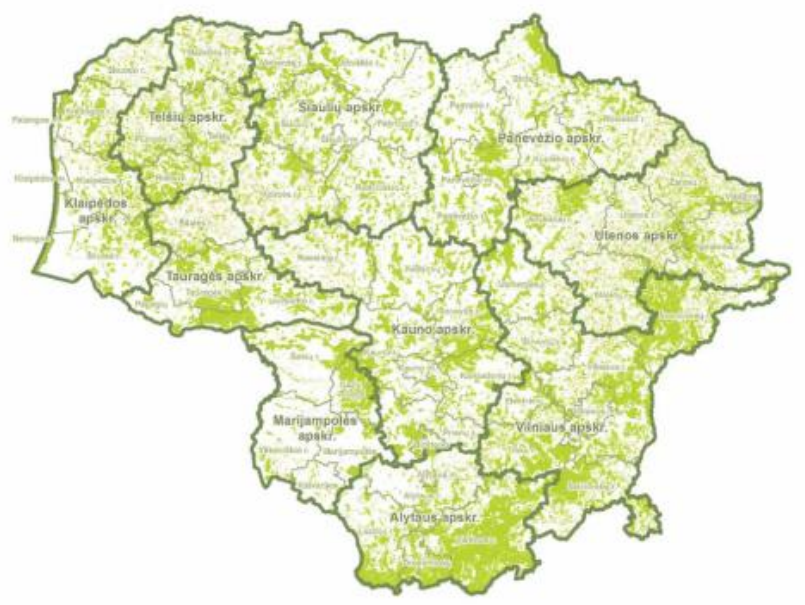

Figure 1. Forest coverage in Lithuania.

ecological and climatic services and preservation of forests.

Implementation of the "Investment in Forest Area Development and Forest Viability" activities will ensure climate change mitigation, preservation of the environment and sustainable forest development.

\section{Forest change tendencies.}

The general plan of the territory of the Republic of Lithuania (Lietuvos..., 2002) states that the afforestation of lands unsuitable for agriculture could increase country's forest areas to $38 \%$.

In the resolution of the Government of the Republic of Lithuania "On Approval of the Program for the Development of the National Forestry Sector 20122020 " (Lietuvos, 2012) it is foreseen that by 2020 , the country's forest coverage needs to be increased to 34.2 percent. The National Environmental Strategy (Lietuvos, 2015) states that the forest coverage by 2030 must rise to $35 \%$ of the total area of Lithuania.
In order to implement the forestry development prospects, from 2018 to 2030, 106,068.87 ha of forests should be planted, which in 2030 would occupy 2,285,026.91 hectares and would make up 35 percent of the country's area.

According to the data of the National Land Service under the Ministry of Agriculture, in 2017 in the country there were $64,007.68$ hectares of unused land and land unfit for agriculture, of which 39,640.34 hectares were not used for agriculture and 24,367.34 hectares of damaged land. The majority of this land is a state property. After afforestation of this land, the country's forest coverage would increase by about 2.94 percent and will occupy 2,242,965.72 hectares and make up 34.36 percent.

To ensure greater ecosystem stability, the country's forest coverage should be at least 35\%. It will help ensure the country's ecological balance, protect the habitats of forest wildlife and vegetation, stop soil erosion, purify air, reduce greenhouse gas emissions

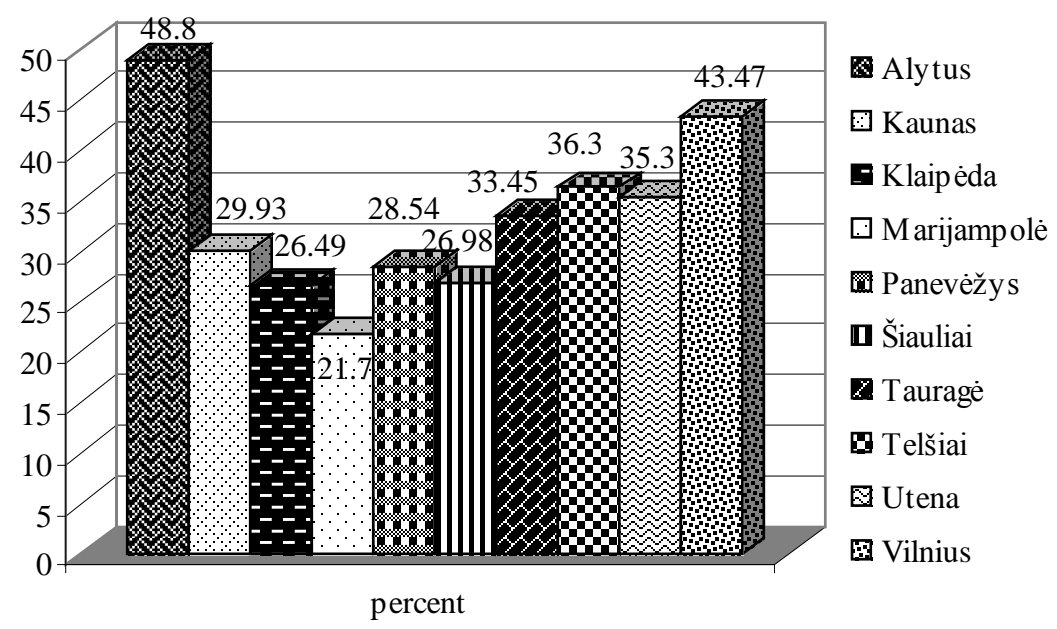

Figure 2. 2017 forest coverage in counties in percentages (Consisted by the author of the article). 
in the air and protect groundwater and surface waters.

In order to preserve and increase the Lithuanian forest resources, forest reproduction on the geneticecological basis of selective and valuable forest reproductive material must be developed, production of forest reproductive material must be optimized, with a view to providing the market with quality forest seedlings in the long term, ensuring adequate protection of forests against diseases, pests and fires.

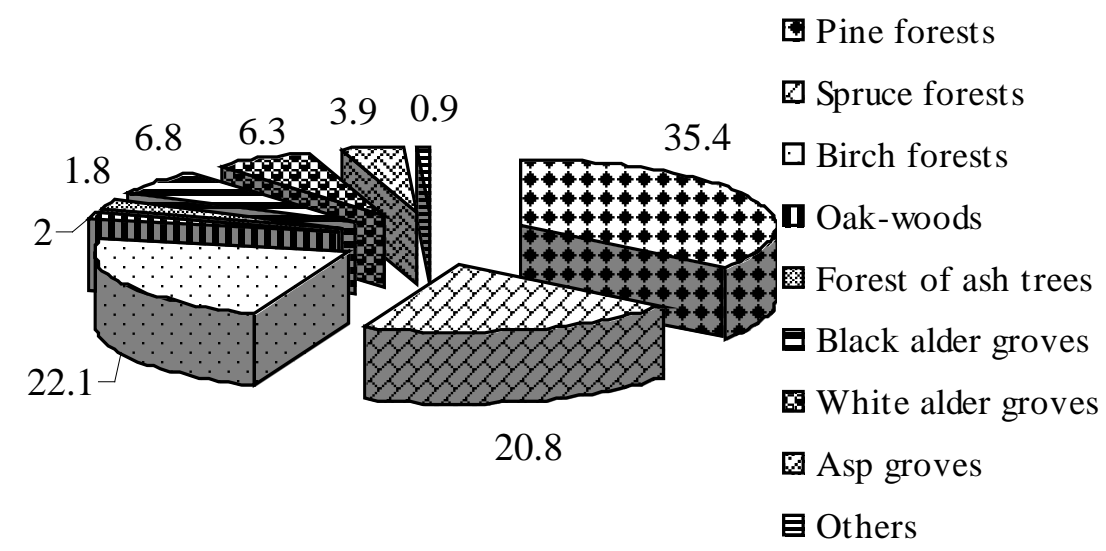

Figure 3. The area occupied by the main types of forest trees as a percentage of the total forest area (Created by the author of the article (Baliuckienè, 2011)).

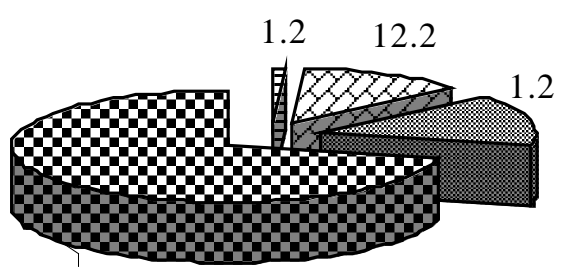

71.4

\author{
日 Group I Forest \\ reserves \\ $\square$ Group II Special- \\ purpose forests \\ Group III \\ Protective forests \\ פ Group IV \\ Commercial forest
}

Figure 4. Distribution of forests by groups in percentages (Created by the author of the article).

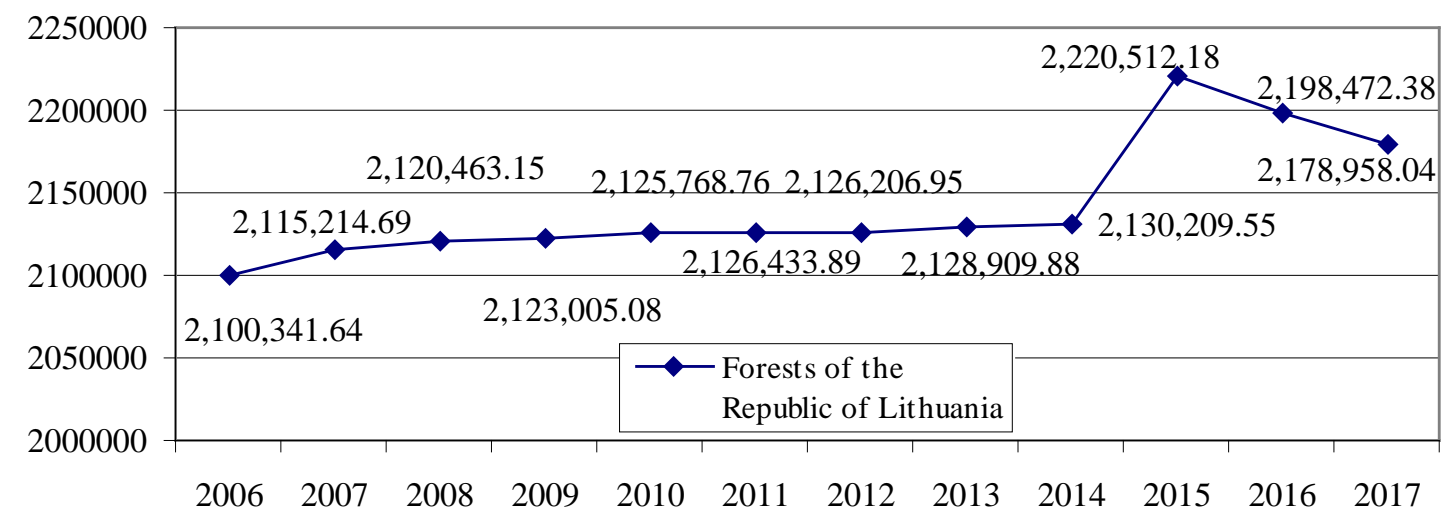

Figure 5. Forest area change in the Republic of Lithuania in 2006 - 2017 (Created by the author of the article according to (Nacionaline, 2006 - 2017)). 


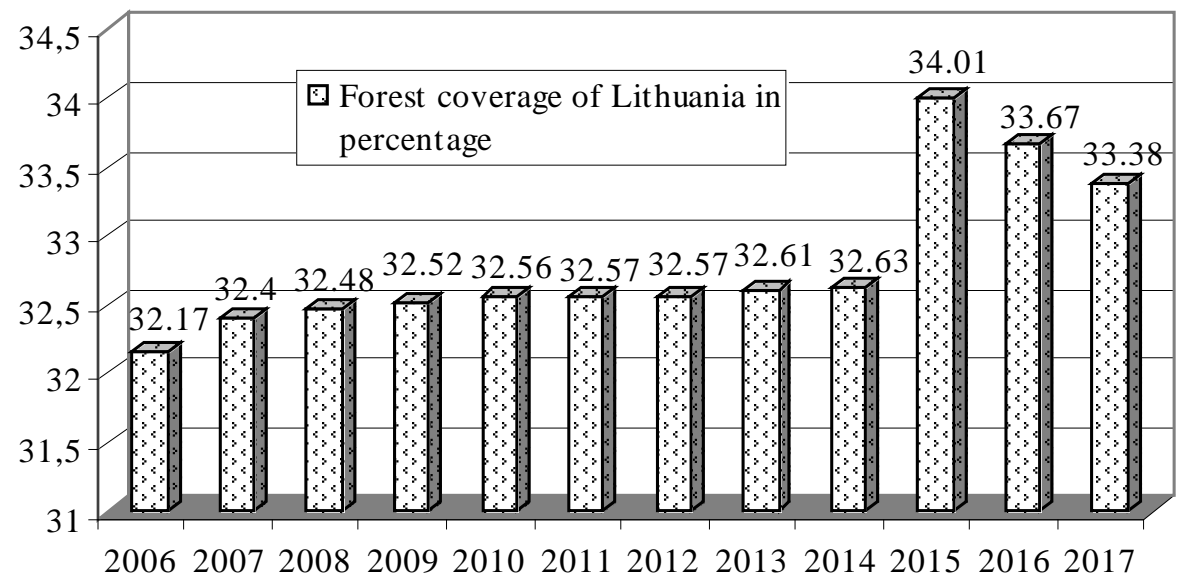

Figure 6. Percentage of forest coverage in the Republic of Lithuania in 2006 - 2017 (Created by the author of the article according to (Nacionalinè, $2006-2017$ )).

\section{Conclusions}

1. In 2017 , forests occupied $2,178,958.04$ ha (33.38\% of the area of Lithuania). The highest forest coverage is in Alytus (48.80\%), Vilnius (43.47\%) and Telšiai $(36.30 \%)$ counties. The lowest forest coverage was established in Marijampole County $(21.70 \%)$. Forests consist of coniferous species (56.2 percent), which are dominated by pine forests. In Alytus, Tauragè, Telšiai, Utena, Vilnius counties predominate forests that are 50-59 years old. Forests in Kaunas, Klaipeda, Marijampole, Panevėžys, Šiauliai are $60-69$ years old.

2. During the period of 2006 - 2017 years, the forest area in Lithuania increased by
$78,616.40$ ha or $3.74 \%$. The largest development of forest areas was recorded in Utena (17,324.13 ha), Śiauliai (14,798.15 ha) and Vilnius $(13,886.17 \mathrm{ha})$ counties, the lowest in Marijampole (169.39 ha) county. The area decreased in the only county of Lithuania - Alytus $(1,894.79$ ha or $0.71 \%)$.

3. In order to implement the forestry development prospects, from 2018 to 2030, 106,068.87 ha of forests should be planted, which would occupy 2,285,026.91 ha in Lithuania and make up 35\% of the country's area.

\section{References}

1. Baliuckienè, A. (2011). Lietuvos miško genetiniai ištekliai. (Lithuanian Forest Genetic Resources). Lietuvos Respublikos aplinkos ministerija. Augalu genu bankas. 36 p. (in Lithuanian).

2. Balevičius, A., Bukantis, A., Bukelskis, E., Ignatavičius, G., Kutorga, E., Mierauskas, P., Rimkus, P., Rukšėnienė, J. Sinkevičius, S., Stankūnavičius, G., Valiuškevičius, G., Zemlys, P., \& Žaromskis, R.P. (2007). Globali aplinkos kaita. (Change of Global Environmental). Vilnius, 299 p. (in Lithuanian).

3. Christensen, N. (2012). The Environment and You. Pearson Education. 434 p.

4. Čapkauskas, G. (2016). Gamtiniai medynų vystymosi trikdžiai: medžių pažeidžiamumas ir lajų defoliacijos rizika. (Natural forest developmental disturbances: the vulnerability of trees and the risk of tailing defoliation). Daktaro disertacija. Akademija, 126 p. (in Lithuanian).

5. Dale, V.H., Joyce, L.A., McNulty, S., Neilson, R.P., Ayres, M.P., Flannigan, M.D., ... Wotton, M. (2001). Climate Change and Forest Disturbances: Climate change can affect forests by altering the frequency, intensity, duration, and timing of fire, drought, introduced species, insect and pathogen. BioScience. Volume 51, Issue 9, pp. 723-734.

6. European Commission. (2010). Green paper. On Forest Protection and Information in the EU: Preparing forest for climate change. $=$ COM (2010) 66 final. 23 p.

7. Food and Agriculture Organization of the United Nations. (2015). State of Europe's Forests. 314 p.

8. Keenan, R.J. (2015). Climate change impacts and adaptation in forest management: a review. Annals of Forest Science. Volume 72, Issue 2, pp. 145-167.

9. Khaine, I., \& Woo, S.Y. (2014). An overview of interrelationship between climate change and forests. Forest Science and Technology. Volume 11, Issue 1, pp. 11-18. 
10. Kohl, M., Lasco, R., Cifuentes, M., Jonsson, M., Korhonene, K.T., Mundhenk, Ph., Navar, J.J., \& Stinson, G. (2015). Changes in forest production, biomass and carbon: Results from the 2015 UN FAO Global Forest Resource Assessment. Forest Ecology and Management. Volume 352. pp. 21-34.

11. Lietuvos Respublikos miškų įstatymas. (The Republic of Lithuania Forestry Law). Iš Valstybės žinios: (1994). Nr. 96-1872. Iš Valstybès žinios: Nr. 96-1872. Suvestinė redakcija. Iš Teisès aktų registras: 2017 04 27. (in Lithuanian).

12. Lietuvos Respublikos Seimo nutarimas (2015). “Dèl Nacionalinés aplinkos apsaugos strategijos patvirtinimo" (Resolution of the Seimas of the Republic of Lithuania "On Approval of the National Environmental Strategy”) (2015 04 16, Nr. XII-1626). Iš Teisės aktų registras: Nr. 6178. (in Lithuanian).

13. Lietuvos Respublikos Vyriausybès nutarimas "Dèl Nacionalinès mišku ükio sektoriaus plètros 2012-2020 metu programos patvirtinimo" (Resolution of the Government of the Republic of Lithuania “On Approval of the Program for the Development of the National Forestry Sector 2012-2020”) (2012 05 23, Nr. 569). Iš Valstybès žinios, Nr. 61-3058. (in Lithuanian).

14. Nacionalinė žemès tarnyba prie Žemès ūkio ministerijos. (2006-2017). Lietuvos Respublikos žemès fondas. (National Land Service under the Ministry of Agriculture. (2006-2017). Land Fund of the Republic of Lithuania). Vilnius. 144 p. (in Lithuanian).

15. Pranckietis, V., \& Bogužas, V. (2010). Agrarinio kraštovaizdžio kitimo priežastys ir problemos. (Causes and problems of agrarian landscape change) Urban sprawl: a city and village link. Urbanistine drieka: miesto ir kaimo sandūra. Mokslo straipsnių rinkinys. pp. 12-19. (in Lithuanian).

16. Pileckas, M. (2004). Aplinkosauginių indikatorių taikymas Lietuvos kraštovaizdžio monitoringui: būklè, problemos, perspektyvos. (Application of Environmental Indicators for Lithuanian Landscape Monitoring: Status, Problems, Perspectives). Geography Yearbook. Geografijos metraštis 37(1-2) t. Vilnius, pp. 112123. (in Lithuanian).

17. Sturrock, R.N., Frankel, S.J., Brown, A.V., Hennon, P.E., Kliejunas, J.T., Lewis, K.J., Worrall, J.J., \& Woods, A.J. (2011). Climate change and forest diseases. Plant pathology. Volume 60, Issue 1, pp. $133-149$. 